\title{
A new approach to assess the impact of extreme temperature conditions on social vulnerability
}

Ibolya Török ${ }^{1}$, Adina-Eliza Croitoru ${ }^{2}$, Titus-Cristian Man $^{3}$

${ }^{1}$ Hungarian Department of Geography, Research Center for Sustainable Development, Babes-Bolyai University, Cluj-Napoca, 5 400006, Romania

${ }^{2}$ Department of Physical and Technical Geography, Research Center for Sustainable Development, Babes-Bolyai University, Cluj-Napoca, 400006, Romania

${ }^{3}$ Department of Regional Geography and Territorial Planning, Research Center for Regional Geography, Babes-Bolyai 10 University, Cluj-Napoca, 400006, Romania

Correspondence to: Ibolya Török (ibolya.torok@ubbcluj.ro)

Abstract. The objective of this research is to develop a set of vulnerability indicators and to analyze the effect of climate factors on social vulnerability. While the main aim of the study is to improve the existing methodology by quantifying the effects of climate change on social vulnerability, it also represents a novel scientific contribution in the field, as it delimits for

15 the first time in the Romanian literature the most vulnerable areas from this point of view. This study aims to facilitate the decision-making processes and planning efforts targeting the increase of resilience and adaptive capacity of local communities. By applying the principal component analysis, we have selected 45 variables and have constructed four aggregated indexes. The Climate-Related Social Vulnerability index (CleSoVI) has pointed out that the largest impact on the current vulnerability of settlements in the test region (Cluj County) can be attributed to the lack of adaptive capacity and increased poverty, the most

20 vulnerable areas being represented by the eastern and north-western parts of the county. From a socio-economic point of view, local authorities' efforts should concentrate on reducing the vulnerability of these regions and preparing them to cope withand adapt to the impact of climate change.

\section{Introduction}

Research on social vulnerability has largely evolved in the last decades due to the increasing occurrence of extreme weather events as a consequence of climate change. Nevertheless, the adoption of the 2030 Agenda with its 17 Sustainable Development Goals (SDGs) has globally committed to taking urgent action to combat climate change and its impact (SDG 13) (UN, 2020). There is a large agreement that vulnerability is a complex phenomenon being influenced by social, economic, environmental, or demographic characteristics, which further determine to a greater or lesser extent the vulnerability of a society.

The Intergovernmental Panel on Climate Change (IPCC) defines vulnerability to climate change as the "degree to which geophysical, biological, and socioeconomic systems are susceptible to and unable to cope with, adverse impacts of climate 
change" (IPCC, 2007: 73). This vulnerability depends on the intensity of climate change and is largely influenced by the sensitivity and adaptability of the exposed system (Huynh et al., 2020)

Over the last decades, different approaches for analyzing vulnerability have been largely developed and widely accepted, which emphasizes the importance of socio-economic, political, or cultural factors on the the exposure, impact and capacity of a society to recover after an unexpected hazard event (Blaikie et al., 1994; Cutter, 1996; Aroca-Jimenez et al., 2017). Social factors include many variables, such as gender, ethnicity, age, education, poverty, and thus they can be regarded as the partial outcome of social inequalities (Cutter et al., 2003; Adger et al., 2004). Under these conditions, marginalized groups of a society are more susceptible and exposed to environmental hazards. A combined application can be found in the analysis of Birkmann

40 (2006). According to this study, vulnerability encompasses physical, social, economic, environmental, and institutional features (Birkmann, 2006), giving an integrated perspective to vulnerability studies (Zanetti et al., 2016). It must be mentioned that not all places are affected by natural hazards in the same manner: e.g., biophysical vulnerability differs from place to place. Tschakert et al. (2019), conducting a climate-related comparative systematic analysis on more than 100 published case studies worldwide, have shown that the same natural hazards can produce different impacts beginning from almost no destruction to irremediable damage across numerous dimensions irrespective of the country's general level of development.

The concept of vulnerability to climate change has been studied by several authors as well (Wisner et al., 2004; Cutter et al., 2009; Tate, 2012; Apotsos, 2019), most studies recognizing, social, economic and cultural elements are of outmost importance, such as biophysical factors (Cutter et. al., 2003; Fussel and Klein, 2006; Preston et al., 2011; Lee, 2014; Debortoli et al., 2019). Consequently, in the last few years, indicator-based methods have represented the most important tools for 50 vulnerability assessment (Kumar et al., 2016; Tapia et al., 2017; Hazbavi et al., 2018; Huynh_et al., 2020). These studies have been elaborated for different scales (countries or cities) and have been applied to locations on almost every continent. In the case of Romania, researching social vulnerability has represented an important preoccupation for several authors, although none of them has included the impact of climate conditions in their work (Stângă and Grozavu, 2012; Armaş and Gavriş; 2013; Bănică and Muntele, 2015; Török, 2017, 2018).

55 Spatially based local vulnerability assessment can support decision-making process in identifying areas and communities, which are most affected by natural hazards with resource allocation and project prioritization more objectively (Birkmann, 2006). This is also important because some of the targeted policies formulated at the national level are not always relevant to the most vulnerable settlements. On the other hand, interventions for economic development, like poverty reduction, food security, and sustainable livelihoods could be formulated at least at the meso level, but the different adaptation practices for increasing the resilience of communities are in the hands of local communities. Therefore, the spatial scale of any vulnerability analysis is a crucial factor. Formetta and Feyen (2019) have analyzed the socio-economic vulnerability to climate-related hazards between 1980 and 2016, stating that there is still a significant climate hazard vulnerability gap between less and welldeveloped countries. Hence, the need to collect and construct disaster-related databases, especially at the local level, should become a priority as it could facilitate the implementation of the disaster risk reduction targets of the Sustainable Development Goals. 
Besides the different approaches used for the conceptualization of social vulnerability, there are also several techniques for measuring it. One of the most widely used and largely accepted methods is the Social Vulnerability Index ( SoVI $\left.{ }^{\circledR}\right)($ Cutter et al. 2003; Fekete, 2009; Holand et al., 2011; Chen et al., 2013; Rufat et al., 2015). Among the weak points of this method is that it attributes an equal impact to all considered factors, therefore recent studies have focused either on using different weighting techniques (Mwale et al., 2015; Frigerio and Amicis, 2016; Török, 2018; El-Zein et al. 2021) or by developing completely new models (Armaș et al., 2017; Bănică et al., 2017).

The objective of this paper is to develop a scientifically based set of vulnerability indicators and calculate the impact of climate factors on people's vulnerability in Cluj County. We adopted the concept of social-environmental vulnerability, which integrates both biophysical (mainly climate related) and social factors and their effects on the human population ("place vulnerability"). As it was already highlighted, this consideration is a common approach and a widely used practice in assessing social vulnerability, as it allows for a more comprehensive characterization (Turner et al., 2003; Adger et al., 2004). The study also aimed to provide a methodological contribution for assessing vulnerability at the local level and to promote the integration of climate change into sectoral and local policies for increasing the climate resilience of the analyzed communities. This approach can be replicated further in different regions of the world. The following parts of the study are as follows: Section 2

80 presents our case study area and data collection methods and Section 3 gives an overview about the methodology. Finally, results and discussions about climate influence on social vulnerability are provided in Sections 4 and 5.

\section{Study area and data}

\subsection{The study area}

Cluj County is situated in the north-western part of Romania. With an area of $6674 \mathrm{~km}^{2}$, it is the $12^{\text {th }}$ largest county of Romania and it includes 5 towns and 81 rural settlements, totalizing 420 villages. In 2020, the population of the county was 736,945 , out of which 480,241 (65.2\%) were living in urban areas. The largest city is Cluj-Napoca, which is an important historical, cultural, educational, and healthcare center, and one of the most developed Romanian cities.

The topography of the county is very complex; it is dominated by hills belonging to the Someș Plateau and, to a much lesser extent, by the north-eastern Apuseni Mountains (part of Western Carpathians), which cover about 30\% of the county. The county has very few planes, but they are substituted by riversides, which are suitable for agricultural activities and for the location of settlements as well. The eastern part of the county partially overlaps over some gas-condensate domes. The altitude varies from less than $300 \mathrm{~m}$ to more than $1800 \mathrm{~m}$ (Fig. 1).

The climate of the analyzed area is moderate, temperate-continental, the altitude influencing the average temperatures and precipitation: in the mountain areas, the average annual temperature is between 4.5 and $6.5{ }^{\circ} \mathrm{C}$ and in the lowlands it varies from 7.5 to less than $10.0^{\circ} \mathrm{C}$ (Fig. 2). Effective precipitation, cumulated in days with an amount equal to or greater than 1.0 $\mathrm{mm}$ ranges from less than 500-600 mm/yr. - on the eastern lee slopes of the mountains under the influence of the foehn local 
wind and most of the lowlands - with more than $1100 \mathrm{~mm} / \mathrm{yr}$. in the mountain areas (Fig. 3 left). The historical highs are at least $20 \%$ above, ranging from 600 to more than $1500 \mathrm{~mm} / \mathrm{yr}$. (Fig. 3 right).

It is of utmost importance to mention that significant changes have been detected over the last decades, mainly in temperature. An increase has been registered both in terms of maximum and minimum temperatures, with a steeper slope in the case of the maximum values (Croitoru and Piticar, 2013). For precipitation, no significant changes have been identified during the last five decades (Bojariu et al., 2015; Croitoru et al., 2016a, 2018).

\subsection{Selection of variables}

After a detailed review of the related literature, a set of 45 simple indicators were selected and tailored to fit the specificity of Cluj County (Table 1). When choosing the indicators, the most important issue was to ensure that the selected variables address the purpose of the research: to identify those vulnerable areas, which are exposed to different climate conditions/effects. The database includes 13 exposure indicators, 17 sensitivity indicators, and 15 indicators for adaptive capacity, grouped into four major categories comprising demographic, socio-economic, built environment, and climate-related factors. The first three groups of indicators were taken from the National Institute of Statistics, based on the 2011 Census data (which is the most recent one conducted in Romania) and the Tempo Online web database.

The climate indicators were derived from daily extreme (maximum and minimum) temperature gridded data for the entire county at a spatial resolution of $0.1^{\circ}$ (on latitude and longitude). The gridded data over a 53-yr period (1961-2013) were made available by the Romanian National Meteorological Administration through the ROCADA database (Dumitrescu and Birsan, 2015). It covers the entire territory of Romania and was developed based on the highest spatial density of quality controlled 115 weather station measurement data in Romania. Datasets are freely available on the World Data Center PANGAEA portal as well. ROCADA derived data have the best spatial resolution and accuracy when compared to other available gridded databases at present, such as E-OBS or CarpatClim (Sfica et al., 2017). From a total number of 35 extreme temperature and precipitation indices calculated from the entire county (World Bank, 2020), we have chosen for this study only those one which showed a statistically significant change over the considered period. Their mean multiannual spatial distribution is presented in Supplementary Material 1.

\section{Methodology}

In assessing social vulnerability to climate change, the most commonly used indicators include person-specific factors like ethnicity, age, gender, state of health, and location-specific factors mainly related to socio-economic status and housing conditions (Cutter and Finch, 2008; Cardona et al., 2012; Otto et al., 2017). For this analysis, the health factor is essential as climate extremes (especially those related to temperature, such as heat and cold waves) have a strong impact on health - for example, in Cluj-Napoca an approximately $14 \%$ increase in general mortality was registered during heat waves. Such events tend to become a threat since they have constantly increased in frequency, duration, and intensity over the last decades in 
Romania (Croitoru et al., 2018). Recent analyses have revealed that old age is one of the most important internal factors for heat-related mortality (Reckien et al., 2017).

Based on reviews of the related literature, as a rule, we have observed that in most cases the majority of indicators have been selected subjectively and adapted to the main characteristics of the analyzed region. This is a common approach, which could be noticed in most of the vulnerability analyses conducted worldwide.

\subsection{Indices calculation}

\subsubsection{Built Environment Vulnerability Index (BEVI)}

135 For constructing the BEVI, we selected 13 variables including housing facilities, quality of housing, quality of living, and green environment. All these data were obtained from the 2011 Census as information regarding housing conditions, in general (such as year of building or housing facilities), and infrastructural development can be found in census databases only. In constructing the index, first we included all relevant variables strongly related to the built environment, but finally, after performing the correlation analysis, we have kept only those indicating a statistically significant correlation $(\alpha<=0.05)$. The

140 included variables are shown in Table 2.

\subsubsection{Demographic Vulnerability Index (DEVI)}

To construct the DeVI, some of the demographic variables were extracted from the 2011 Census and they were amended by data obtained from the Tempo online database made available by the Romanian National Institute of Statistics. It contains data from 1990 onwards both at regional and local levels. We selected variables, which were available at the local level and for all

145 settlements in the county. After running the correlation analysis, we retained only seven highly correlated indices, grouped in three main categories: family structure, demographic vitality, as well as gender and mobility (Table 2).

\subsubsection{Socio-Economic Vulnerability Index (SEVI)}

The development of SEVI is based on 12 variables: which include education and occupation, health and accessibility, as well as general wellbeing. Besides the above-mentioned 2011 Census and the Tempo online database, we have also used local tax income data provided by the Ministry of Regional Development and Public Administration (MRDPA). Another composite index, included in the construction of SEVI, is the Local Human Development Index (LHDI) (Sandu, 2016). This is based on the United Nations Human Development Index methodology, but the used socio-economic variables allow the comparison of rural and urban localities as well (Sandu, 2016) (Table 2).

\subsubsection{Climate impact Vulnerability Index (CliVI)}

The development of the CliVI is based on 13 extreme temperature indices, largely used to assess the climate change worldwide (Table 2). As the most relevant and accelerated change in Romania was detected for extreme temperatures (Bojariu 
et al., 2015; Croitoru et al., 2016b; 2018), for this study, a set of 13 extreme temperature indices was chosen to assess the social vulnerability to climate change in Cluj County. They were selected from the core list established by the Expert Team for Climate Change Detection, Monitoring and Indices (ETCCDMI) and by the Commission for Climatology Expert Team on Sector-Specific Climate Indices (ET-SCI) of the World Meteorological Organization. From a multitude of indices (Alexander and Harolds, 2016), we retained for this study only those ones indicating statistically significant changes at the scale of the entire county (World Bank, 2020). They are used in this paper as "exposure" variables and are listed in Table 1, in including their names, definitions, and measurement units. The spatial distribution of their multiannual values are presented in Supplementary Material 1. The method used for trend detection was the least-square method and the statistical significance was established at a level of 0.05 . The index datasets for the 53-yr period (1961-2013) have been obtained by using $\mathrm{R}$ version of the ClimPACT2 application (Alexander and Harolds, 2016).

\subsection{General vulnerability assessment}

To assure that components with higher variance influence more the overall vulnerability, in this study, we applied a weighting method based on each principal component percentage variance. Török (2018) successfully used the same approach previously

$$
W_{i}=\frac{\text { Explainable variance }}{\text { Total percent varianced explained }} * 100
$$

In the first step, the PCA was run for the built environment indicators resulting in the BEVI, then for the demographic dimension leading to the DeVI, for the socio-economic indices (SEVI), as well as for the climate impact factors by proposing the CliVI, based on the methodology presented by Török (2018) using Eq. (2):

CLeSoVI $=\sum_{i=1}^{n} B E V I+\operatorname{DeVI}+\operatorname{SEVI}+\operatorname{CliVI}\left(\frac{F_{i}}{v_{i}} * w_{i}\right)$,

where, $n$ - the number of territorial units; $F_{i}$ - the resulting number of factors; $v_{i}$ - the number of variables included in each factor; $w_{i}$ - the assigned weight for each factor.

In the second step, the Climate related Social Vulnerability Index (CleSoVI) for all settlements in Cluj County was calculated by using Eq. (3).

CleSoVI $=\sum_{i=1}^{n}$ BEVI $-\left(\frac{F_{1}}{5} * 45.4\right)+\left(\frac{F_{2}}{3} * 19.1\right)+\left(\frac{F_{3}}{3} * 11.5\right)+\left(\frac{F_{4}}{2} * 7.8\right)+\sum_{i=1}^{n} D e V I+\left(\frac{F_{5}}{3} * 40.7\right)+\left(\frac{F_{6}}{2} * 30.5\right)+$ $\left.\left(\frac{F_{7}}{2} * 14.6\right)+\sum_{i=1}^{n} \operatorname{SEVI}-\left(\frac{F_{8}}{6}\right) * 45.5-\left(\frac{F_{9}}{3} * 19.8\right)+\left(\frac{F_{10}}{3} * 10.8\right)+\sum_{i=1}^{n} \operatorname{CliVI}\left(\frac{F_{11}}{11} * 78.9\right)+\left(\frac{F_{12}}{2}\right) * 12.7\right) \mathrm{Q}$

The detailed CleSoVI construction procedure is presented as a flowchart in Fig. 4.

\subsection{Level of vulnerability}

Using a weighting methodology according to the variance explained by each factor, the composite CleSoVI scores were

divided into five categories presenting the level of vulnerability. The calculation was based on the standard deviation from the mean, where negative values represent low social vulnerability while positive values indicate a high degree of vulnerability. 


\subsection{Mapping}

For this research, the geospatial and geostatistical analyses were performed by employing the ArcGIS v10.6. IDW interpolation was applied to a regular grid-shaped point dataset to create maps of extreme temperature indices for Cluj County. The IDW technique computes an average value for each unsampled location using values from nearby weighted locations. For this paper, the input data were projected in Stereo 1970 (Romania's National Projection System).

\section{Results and Discussion}

According to PCA, from the initially selected 45 variables we got 12 latent factors grouped into four categories, which explained $83.9 \%, 85.9 \%, 76.2 \%$, and, respectively, $89.6 \%$ of the variance. The high value of Kaiser-Meyer-Olkin (KMO) measurement confirmed the adequacy of the correlation matrices, while Bartlett's test revealed a high probability that the selected variables are suitable for the analysis $(\mathrm{p}<0.001)$, too. The description of the twelve components with component loadings and their effect on social vulnerability is presented in Table 2.

\subsection{Analysis of BEVI}

The first index, BEVI has four main components and the total variance explained is $83.9 \%$. This dimension has a significant positive impact on the settlements' accessibility to different services, incorporating elements describing the overall quality of living and quality of housing. On the one hand, limited access to basic services like access to piped water and sewage network, the share of wooden houses make people more vulnerable, especially those from rural areas and highly isolated mountainous regions (southwestern and northeastern parts of the county). On the other hand, population and housing density contributes to anthropogenic excess heat, and the modified urban climate could have further impact on people health by appearing heat islands (Fig. 5a).

\subsection{Analysis of DEVI}

According to the PCA, the most vulnerable communities are those with a high rate of elderly and widows/widowers as well as the ones where the demographic dependency ratio is well above the county average, all above-mentioned variables loading positively on this dimension. Communities with a high rate of elderly are especially vulnerable not only that they are physically frail and thus much more exposed to risk, but they might be much less able to help themselves when faced with extreme weather conditions. In the analyzed area, where the share of elderly people is constantly growing at the expense of the young population, the phenomenon raises even more issues related to vulnerability. Especially, the south-western and partially northwestern areas of the county are characterized by a relative unbalanced age structure due to the high demographic dependency ratio (Fig. 5b). 
Some of the most vulnerable population groups are strongly related to socio-economic factors, including education and occupation, health and accessibility, and general well-being. Individuals with a low level of education have access to fewer employment options and they usually have a low standard of living. Consequently, they have limited access to warning information and a reduced ability to understand the true impact of disasters (Morrow, 1999; Cutter et al. 2003). In general, different occupations require different education levels and skills, hence leading to different levels of income. The unqualified workforce and people working in primary activities are the most vulnerable because of their dependency on natural resources (Chen et al., 2013). These categories are also highly vulnerable to natural disasters due to the lack of adequate income levels and material resources, which considerably decrease their ability to recover afterwards. Except for the central part of the analyzed area, which is the most developed one, the rest of the county is characterized by a strong peripheralisation due to their dependence on agriculture, low income, and low education level (Fig. 5c).

\subsection{Analysis CliVI}

The Climate impact Vulnerability Index (CliVI) encompasses 13 variables with a high explanation power (cumulative variance explained is $89.6 \%$ ). The maps presenting the spatial distribution of the indices are presented in Supplementary Material 1. It is easy to identify a strong west-east gradient according to extreme temperature conditions, mainly influenced by the topography and altitude. The western part is dominated partly by mountains and high hills where lower temperatures and the intensity (magnitude) of cold waves have a negative impact on people's vulnerability, aggravated by the low accessibility (Fig. $5 \mathrm{~d})$.

According to the International Disaster Database, the most severe cold waves and winter conditions in the last two decades occurred in the years $2002,2005,2008$, and 2009 , when outside temperatures fell below $-34^{\circ} \mathrm{C}$, resulting in the death of 132 people at the national level (there are no data available at the county level). In contrast, in the eastern part where agriculture represents the dominant economic activity, the duration and frequency of heat wave events, usually associated with persistent draught, make people and places more vulnerable. If we consider the same database, the most severe weather conditions in the analyzed county have been recorded in 2004 when outside temperatures reached $38{ }^{\circ} \mathrm{C}$ leading to 27 deaths in Romania (CRED, 2020).

\subsection{Analysis CleSoVI}

The resulted CleSoVI factors show that $19.8 \%$ of settlements fall into low and very low vulnerability categories ( -1.5 to -0.5 Std. Dev), whereas $32.1 \%$ of settlements are characterized with high and very high social vulnerability (0.5 - 1.5 Std. Dev.) (Fig. 6).

According to the obtained factor scores, the western, north-western, and eastern parts of the county represent the most vulnerable areas. These settlements are outmost exposed not only to extreme temperature events, but they are fragile from 
demographic and partially socio-economic points of view as well. Within those settlements, social vulnerability is mainly influenced by high emigration, demographic ageing, low level of education, but also by the economic structure, subsistence farming being the most important preoccupation of the population living here. Beside the fact that agriculture is highly exposed to environmental factors, the relatively low wages represent the cradle of rural poverty. At the same time, the average and extreme temperature-related conditions can have an impact on the vulnerability of the population. Among them, persistent heat waves seem to have the most important consequences. By contrast, the lowest vulnerability can be found in urban areas and suburban localities (mainly near big cities) where, even though the population and housing density is higher compared to other settlements, there is an increased adaptive capacity due to the overall socio-economic conditions and the demographic characteristics (Figure 6).

Hedlund et al. (2018) using the Notre Dame Global Adaptation Index (ND-GAIN, 2012) highlighted that even though climate risks show a strong correlation with economic development and geographical position, there is a need to support a strong adaptation planning mainly in the framework of international cooperation to reduce them in global systems. Over the last years, due to the pressure of global warming, adaptation to climate change represented an important step on the Romanian political agenda as well. The National Strategy for Climate Change in Romania was approved in 2013, focusing on the reduction of vulnerability in specific sectors like agriculture, energy, water resources, transport, industry, construction, urban planning, insurance, biodiversity, human health, tourism, forestry, infrastructure and recreational activities (MECC, 2013). According to the experts' long-term estimates (2041-2070 and 2071-2100), the temperature continues to increase alongside the reduction of average precipitation during the warm season (MECC, 2013). Under these circumstances, it is essential to take into consideration the effect of long-term climate change on people's vulnerability, their exposure, and adaptive capacity.

One of the main consequences of climate change could be already observed in agriculture activities. The weak adaptation capacity of society is linked to the aforementioned demographic problems (high demographic ageing and the decline of the rural population), economic problems (low competitiveness of small farms, high fragmentation of agricultural areas), as well as social problems (massive youth migration from rural areas, strong peripheralisation process). However, the changes in agroclimatic conditions (GDDgrow index) have revealed a consistent improvement of thermal conditions for crop growing. This is particularly important mostly in the eastern part of the analyzed region, where the main livelihood opportunity is related to agriculture, and where the population should be aware that recent and more productive hybrids could be successfully cultivated under new climate conditions (Croitoru et al., 2020). Under these circumstances, a proactive policy could facilitate the sustainable transition to a more diverse agro-ecosystem, avoiding the path dependency associated with a monoculture production approach (Roesch-McNally, 2018).

275 The second issue is strongly related to water resources: due to climate change and the frequency of extreme weather phenomena, warmer and shorter winters have led to the decrease of the snowcaps and to the early melting of snow (MECC, 2013). This situation particularly affects the southern and south-western parts of the county where well-known ski resorts are located and where winter tourism accounts for a significant share of income. In addition, the problem of decreasing water resources in both quantity and quality (Gurzau et al., 2010) is accompanied by the increase of water demand generated by 
280 extreme high temperatures associated with dry periods during summer. As the geological structure in the eastern part of the county has a significant impact on the quality of water resources, the settlements are prone to a particular anthropogenic and natural vulnerability and as a result, landslides and sheet flows characterize the landscape. Under these circumstances, the sensitivity of local communities to any climatic hazards has risen, while adaptation strategies have failed to keep pace.

A pressing problem, which most urban areas face, is the effect of persistent heat waves under climate change conditions. Their impacts are more intense in densely populated urban areas due to their added heat stress overlapping with the urban heat islands (Herbel et al., 2017). Analyzing how individuals or households respond to the local impact of global climate change is an important issue for policy makers to elaborate strategies for exposure reduction and adaptation capacity improvement. Therefore, vulnerability assessment is an important part of adaptation planning and the CLeSoVI index developed in the current paper could represent the first step in this sense, offering the possibility to be tested and applied in other regions as well. At a

290 national scale, an integrated Local Social Vulnerability Index was developed and successfully used to measure the population's vulnerability to flood hazards (Török, 2018). We consider that in the near future it is necessary to carry out similar analyses for smaller territorial units, taking into account different factors of natural disasters. This would be essential to identify the socio-economic and demographic characteristics, which increase the capacity of the population to resist, cope with, and recover from disasters (Cutter et al., 2010; Frazier et al., 2014). By pinpointing the areas with the greatest need for vulnerability reduction, the developed index could help policy-makers prioritize development measures.

The importance of community-based adaptation to climate-related vulnerability, capacity building, and choices about different information channels seem to be crucial (Ford et al., 2018). At present, there are only three cities in Romania who have already elaborated a local strategy for climate change adaptation. Not surprisingly, no rural settlement in Romania has such strategy. The present analysis serves as an important tool for local and regional authorities to recognize the natural and socio-economic problems which make these communities more vulnerable, to elaborate local development strategies so that to increase the coping capacities of the population living in those areas. However, since the European Green Deal is a roadmap for making the EU's economy and society sustainable and more resilient to climate change by turning climate and environmental challenges into opportunities across all policy areas and making the transition just and inclusive for all, local communities and authorities could benefit from adaptation support (European Commission, 2020).

The impact of internationally financed climate change adaptation projects on local communities indicated that a better approach for strengthening the limited capacity of a community is to promote bottom-up adaptation projects (Manuamorn et al., 2020). However, the problems resulting from the lack of cooperation between local authorities and communities are still present, making it difficult to share responsibilities for mitigating actions, which could help overcome the negative impact of climate change. Among the most appropriate and effective long-term solutions are those implemented in formal education to

310 increase awareness and (in)form children from an early age for developing adaptive behavior. In the case of the elderly, which are most exposed to climate-induced heat stress, understanding the fact of continuous monitoring their health status to increase the level of preparedness are of outmost importance. At the same time, CleSoVI can help local policy makers, civil societies, 
and communities to further examine the roots of risk and vulnerability to make the right decision for mitigation measures, preparedness, and response planning as well as recovery (Török, 2018).

\section{Conclusion}

The present paper aims to develop an in-depth analysis based on socio-economic variables to understand what makes a community more vulnerable compared to another. To better assess the social vulnerability of the analyzed region, the results of this research were obtained based on a significant selection of socio-economic and climate-related variables, an improved methodological assessment, and a GIS-based approach. This study represents a first attempt for understanding the spatial relationship between social vulnerability and climate change, offering the possibility to be tested in other regions as well. As the analysis revealed, the most vulnerable communities could be found in the eastern and north-western peripheral rural areas, which are further affected by climate-induced negative impacts. Usually, these settlements are characterized by multiple social and economic disadvantages, which make it difficult to cope with the impact of any natural hazards. The present analysis represents an important step towards developing more adequate response strategies and towards helping local decision makers plan better to adapt and cope with the impact of climate change, taking advantage of the opportunities and support attributed to the European Green Deal (European Commission, 2020).

The study presents some limitations. Even though the analysis can offer a holistic approach by combining various social, economic, demographic, and climate-related/e indicators, some of them are not up to date as it could be found only in the 2011 Census. This makes it difficult to give a precise situation picture about/of the analyzed territories. The second limitation is

330 strongly related to the static character of the analysis. By comparing different periods, it could further help to identify the changes of people's vulnerability, their coping, and adaptive capacity.

Overall, our paper is novel from the perspective of the used scale and the proposed method, which can be applied for any local community, with some adjustments to capture the local specificity of the considered focus area.

\section{Data availability}

Row climatic data for extreme temperature calculation are freely available as presented in Dumitrescu, A., Birsan, MV (2015) ROCADA: a gridded daily climatic dataset over Romania (1961-2013) for nine meteorological variables, Natural Hazards 78(2):1045-1063. DOI: 10.1007/s11069-015-1757-z.

Raw social and economic data are available on https://insse.ro/cms/ro/content/sdds-plus-0 and on http://www.recensamantromania.ro/.

\section{Author contributions}

TI and AEC developed the methodology and TI and TCM implemented and tested it in GIS, obtaining results analysed also by AEC. TI prepared the paper with contributions from all co-authors. 


\section{Competing Interests}

The authors declare that they have no conflict of interest.

\section{References}

Adger, W.N., Brooks, N., Bentham, G., Agnew, M., and Eriksen, S.: New indicators of vulnerability and adaptive capacity, Tyndall Centre Technical Reports, Tyndall Centre for Climate Change Research Norwich, 2004, http://www.tyndall.ac.uk/ sites/default/files/it1_11.pdf, last access: 17 November 2016.

Alexander, L. and Herold, N.: ClimPACT2 Indices and Software, The University of South Wales, Sydney, Australia, 2016, https://github.com/ARCCSS-extremes/climpact2, last access: 23 November.

Apotsos, A.: Mapping relative social vulnerability in six mostly urban municipalities in South Africa, Appl. Geogr., 105, 86101, https://doi.org/10.1016/j.apgeog.2019.02.012, 2019.

Aroca-Jimenez, E., Bodoque, J.M., Garcia, J. A., and Diez-Herrero, A.: Construction of an integrated social vulnerability index in urban areas prone to flash flooding, Nat. Hazards Earth. Syst. Sci., 17, 1541-1557, https://doi.org/10.5194/nhess17-1541-2017, 2017.

Armaş, I., and Gavriş, A.: Social vulnerability assessment using spatial multi-criteria analysis (SEVI model) and the Social Vulnerability Index (SoVI model) - a case study for Bucharest, Romania, Nat. Hazard. Earth. Sys., 13, 1481-1499. https://doi.org/10.5194/nhess-13-1481-2013, 2013.

Armaş, I., Toma-Danila, D., Ionescu, R., and Gavriş, A.: Vulnerability to earthquake hazard: Bucharest case study, Romania, Int. J. Disaster Risk. Sci., 8, 182-195, https://doi.org/10.1007/s13753-017-0132-y, 2017.

Bănică, A., and Muntele, I.: Urban vulnerability and resilience in post-communist Romania (Comparative case studies of Iasi and Bacau cities and Metropolitan areas). Carpath. J. Earth Env. 4, 159-171. 2015.

Bănică, A., Roșu, L., Muntele, I., and Grozavu, A.: Towards urban resilience: A multi-criteria analysis of seismic vulnerability in Iasi city (Romania), Sustain., 9, https://doi.org/10.3390/su9020270, 2017.

Birkmann, J.: Measuring Vulnerability to Promote Disaster resilient Societies: Conceptual Frameworks and definitions, in: Measuring Vulnerability to Natural Hazards - Towards Disaster Resilient Societies, edited by: Birkmann, J., United Nations University Press, Tokyo, 9-54. 2006.

Blaikie, P., Cannon, T., Davis, I., and Wisner, B. (eds.): At risk: Natural hazards, people's vulnerability and disasters, Routledge, London, 1994.

Bojariu R., Bîrsan, M.V., Cică, R., Velea, L., Burcea S., Dumitrescu, A., Dascălu, S.I., Gothard M., Dobrinescu A., Cărbunaru, F., and Marin L.: Schimbările climatice-de la bazele fizice la riscuri și adaptare (Climate change - from physical bases to risks and adaptation), Printech Press, Bucharest, 2015. 
Centre for Research on the Epidemiology of Disasters (CRED): The International Disaster Database (EM-DAT), www.emdat.be, last access: 18 June 2020.

Cardona, O.D., Aalast, M.K, Bikmann, J., Fordham, M., McGregor, G., and Mechler, R.: Determinants of risk: exposure and vulnerability, in: Managing the risks of extreme events and disasters to advance climate change adaptation, edited by: Cardona, O.D., and Allst, M., Cambridge University Press, Cambridge. 2012.

Chen, W.F., Cutter, S.L., Emrich, C.T., Shi, P.: Measuring social vulnerability to natural hazards in the Yangtze River Delta region, China, Int. J. Disaster Risk Reduct., 4, 169-181, https://doi.org/10.1007/s13753-013-0018-6, 2013.

Croitoru A.E., and Piticar, A.: Changes in daily extreme temperatures in the extra-Carpathians regions of Romania, Int. J. Climatol., 33, 1987-2001, https://doi.org/ 10.1002/joc.356, 2013.

Croitoru A.E., Piticar, A., and Burada, D.C.: Changes in precipitation extremes in Romania, Quaternary Intern., 415, 325335, https://doi.org/10.1016/j.quaint.2015.07.028, 2016a.

Croitoru A.E., Piticar, A., Ciupertea, F.A., and Rosca, C.F. Changes in heat wave indices in Romania over the period 19612015, Global Planet. Change., 146, 109-121, http://dx.doi.org/10.1016/j.gloplacha.2016.08.016, 2016b.

Croitoru A.E., Piticar, A., Sfìcă, L., Harpa, G.V., Roșca, C.F., Tudose, T., Horvath, C., Minea, I., Ciupertea, F.A., and Scripcă, A.S.: Extreme temperature and precipitation events in Romania, Editura Academiei Române, 359 p., 2018.

Croitoru, A.E., Man. T.C., Vâtcă, S.D., Kobulniczky, B., and Stoian. V.: Refining the Spatial Scale for Maize Crop AgroClimatological Suitability Conditions in an Area with Complex Topography towards a Smart and Sustainable Agriculture. Case Study: Central Romania (Cluj County). Sustain., 12, https://doi.org/10.3390/su12072783, 2020.

Cutter, S.L.: Vulnerability to environmental hazards, Prog. Hum. Geogr., 20, 529-539, https://doi.org/10.1177/030913259602000407, 1996.

Cutter S.L., Boruff, B.J., and Shirley, W.L.: Social vulnerability to environmental hazards, Soc. Sci. Q., 84, 242-261, https://doi.org/10.1111/1540-6237.8402002, 2003,

Cutter S.L., and Finch, C.: Temporal and spatial changes in social vulnerability to natural hazards, PNAS 7, 2301-2306, https://doi.org/10.1073/pnas.0710375105, 2008.

Cutter, S.L., Emrich, C.T., Webb, J.J., and Morath, D.: Social Vulnerability to Climate Variability Hazards: A Review of the Literature, Final Report to Oxfam America, http://citeseerx.ist.psu.edu/viewdoc/download?doi=10.1.1.458.7614\&rep=rep1\&type=pdf, last access: 17 October 2017, 2009.

Cutter, S.L., and Morath, D.P.: The evolution of Social Vulnerability Index (SoVI). Measuring Vulnerability to Natural Hazards. Towards Disaster Resilience, edited by: Birkmann, J., 2nd ed., United Nations University Press: Bonn, Germany, 304-321, 2013.

Cutter, S. L., Burton, C. G., and Emrich, C. T. Disaster Resilience Indicators for Benchmarking Baseline Conditions, J. Homel. Secur. Emerg., 7, 1-24, https://doi.org/10.2202/1547-7355.1732, 2010. 
Debortoli, N.S., Clark, D.G., Ford, J.D., Sayles, J.S., and Diaconescu, E.P.: An integrative climate change vulnerability index for Arctic aviation and marine transportation. Nat. Comm., 10, 2596, https://doi.org/10.1038/s41467-019-10347-1, 2019.

Dumitrescu, A., and Birsan, M.V.: ROCADA: a gridded daily climatic dataset over Romania (1961-2013) for nine meteorological variables, Nat. Hazards., 78, 1045-1063, https://doi.org/10.1007/s11069-015-1757-z, 2015.

El-Zein, A., Ahmed, T., and Tonmoy, F.: Geophysical and social vulnerability to floods at municipal scale under climate change: The case of an inner-city suburb of Sydney., Ecol. Ind., 121, https://doi.org/10.1016/j.ecolind.2020.1069_2021.

European Commission: European Green Deal, https://ec.europa.eu/info/strategy/priorities-2019-2024/european-greendeal_en, last access: 20 July 2020, 2020.

Fekete, A.: Validation of social vulnerability index in context to river floods in Germany, Nat. Hazards Earth Syst. Sci., 9 , 393-403, https://doi.org/10.5194/nhess-9-393-2009, 2009.

Ford, J. D., Sherman, M., Ford, L.B., Llanos, A., Carcamo, C., Harper, S., Lwasa, S., Namanya, D., Marcello, T., Maillet, M., and Edge, V.: Preparing for the health impacts of climate change in Indigenous communities: The role of communitybased adaptation, Global Environ. Chang., 49, 129-139, https://doi.org/10.1016/j.gloenvcha.2018.02.006, 2018.

Formetta, G., and Feyen, L.: Empirical evidence of declining global vulnerability to climate-related hazards, Global. Environ. Chang., 57, 1-9, https://doi.org/10.1016/j.gloenvcha.2019.05.004, 2019.

Frazier, T. G., Thompson, C. M., and Dezzani, R. J.: A framework for the development of the SERV model: A Spatially Explicit Resilience-Vulnerability model, Appl. Geogr., 51, 158-172, https://doi.org/10.1016/j.apgeog.2014.04.004, 2014. Frigerio, I., and Amicis M. De.: Mapping social vulnerability to natural hazards in Italy: a suitable tool for risk mitigation strategies, Environ. Sci. Policy, 63, 187-196, https://doi.org/10.1016/j.envsci.2016.06.001, 2016.

Fussel, H. M., and Klein, R. J. T.: Climate change vulnerability assessments: An evolution of conceptual thinking, Climatic Change, 75, 301-329, https://doi.org/10.1007/s10584-006-0329-3, 2006.

Gurzau, A. E., Popovici, E., Pintea, A., Popa, O., Pop, C., and Dumitrascu, I.: Quality of surface water sources from a central Transylvanian area as a possible problem for human security and public health, Carpath. J. Earth Env., 5, 119-126, 2010.

Hazbavi, Z., Baartman, J. E. M., Nunes, J. P., Keesstra, S., Sadeghi, S. H.: Changeability of reliability, resilience and vulnerability indicators with respect to drought patterns, Ecol. Indic., 87, 196-208, https://doi.org/10.1016/j.ecolind.2017.12.054, 2018.

Hedlund J., Fick, S., Carlsen, H., Benzie, M.: Quantifying transnational climate impact exposure: New perspectives on the global distribution of climate risk, Global Environ. Change, 52, 75-85, https://doi.org/10.1016/j.gloenvcha.2018.04.006, 2018.

Herbel, I., Croitoru, A. E., Rus, A.V., Roşca, C. F., Harpa, G. V., Ciupertea, A. F., and Rus, I.: The impact of heat waves on surface urban heat island and local economy in Cluj-Napoca city, Romania, Theor. Appl. Climatol. 133, 681-695, https://doi.org/10.1007/s00704-017-2196-4, 2017.

Holand, I. S., Lujala, P., and Rød, J. K.: Social vulnerability assessment for Norway: A quantitative approach, Nor. Geogr. Tidsskr., 65, 1-7, https://doi.org/10.1080/00291951.2010.550167, 2011. 
Huynh, H., Do, A., and Dao, T.: Climate change vulnerability assessment for Can Tho city by a set of indicators, Int. J. Clim. Change Str., 12, 147-158, https://doi.org/10.1108/IJCCSM-01-2018-0003, 2020.

Intergovernmental Panel on Climate Change (IPCC): Climate change 2007: impacts, adaptation and vulnerability, Contribution of working Group II to the fourth assessment report of the intergovernmental panel on climate change, Cambridge: Cambridge University Press, p. 976, 2007.

Kumar, S., Raizada, A., Biswas, H., Srinivas, S., and Mondal, B.: Application of indicators for identifying climate change vulnerable areas in semi-arid regions of India, Ecol. Indic., 70, 507-517, https://doi.org/10.1016/j.ecolind.2016.06.041, 2016.

Lee, Y. J.: Social vulnerability indicators as a sustainable planning tool, Environ. Impact Asses., 44, 31-42, https://doi.org/10.1016/j.eiar.2013.08.002, 2014.

Manuamorn, O.P., Biesbroek, R., and Cebotari, V.: What makes internationally-financed climate change adaptation projects focus on local communities? A configurational analysis of 30 Adaptation Fund projects, Global Environ. Chang., 61, 118, https://doi.org/10.1016/j.gloenvcha.2020.102035, 2020.

Ministry of Environment and Climate Change (MECC): Romania's Sixth National Communication on Climate Change and First Biennial Report to the United Nations Framework Convention on Climate Change. https://unfccc.int/sites/default/files/6th_nccc_and_1st_br_of_romania\%5B1\%5D.pdf,_last access: 16 April 2020, 2013.

Morrow, B.: Identifying and mapping community vulnerability, Disasters, 23, 1-18, https://doi.org/10.1111/1467$7717.00102,1999$.

Mwale, F. D., Adeloye, A. J., and Beevers, L.: Quantifying vulnerability of rural communities to flooding in SSA: A contemporary disaster management perspective applied to the Lower Shire Valley, Malawi, Int. J. Disaster Risk Reduct., 12, 172-187, https://doi.org/10.1016/j.ijdrr.2015.01.003, 2015.

Otto, I. M., Reckien, D., Reyer, C. P. O., Marcus, R., Le Masson, V., Jones, L., Norton, A., and Serdeczny, O.: Social vulnerability to climate change: a review of concepts and evidence, Reg. Environ. Change, 17, 1651-1662, https://doi.org/10.1007/s10113-017-1105-9, 2017.

Preston, B. L., Yuen, E. J., Westaway, R. M.: Putting vulnerability to climate change on the map: A review of approaches, benefits, and risks, Sustain. Sci., 6, 177-202, https://doi.org/10.1007/s11625-011-0129-1, 2011.

Reckien, D., Creutzig, F., Fernandez, B., Shuaib L, M., Restrepo T. M., McEvoy, D., and Satterthwaite, D.: Climate change, equity and the Sustainable Development Goals: an urban perspective, Environ. urban., 29, 159-182, https://doi.org/10.1177/0956247816677778, 2017.

Roesch-McNally, G. E.: US Inland Pacific Northwest wheat farmers' perceived risks: motivating intentions to adapt to climate change? Environ., 5, 1-20, https://doi.org/10.3390/environments5040049, 2018.

Rufat, S., Tate, E., Burton, C., and Maroof, S.A.: Social vulnerability to floods: review of case studies and implications for measurement, Int. J. Disaster Risk Re., 14, 470-486, https://doi.org/10.1016/j.ijdrr.2015.09.013, 2015.

Sandu D.: Local Human Development Index, https://www.researchgate, last access: 19 June 2016. 
Sfîcă, L., Croitoru, A. E., Iordache, I., and Ciupertea, A. F.: Synoptic Conditions Generating Heat Waves and Warm Spells in Romania, Atmosphere, 8, https://doi.org/10.3390/atmos8030050, 2017.

Stângă, I. C., and Grozavu, A.: Quantifying human vulnerability in rural areas: case study of Tutova Hills (Eastern Romania). Nat. Hazards Earth Syst. Sci, 12, 1987-2001, https://doi.org/10.5194/nhess-12-1987-2012, 2012.

Tapia, C., Abajo, B., Feliu, E., Mendizabal, M., Martinez, J.A., Fernández, J.G., Laburu, R., and Lejarazu, A.: Profiling urban vulnerabilities to climate change: an indicator-based vulnerability assessment for European cities, Ecol. Indic. 78, 142-155, https://doi.org/10.1016/j.ecolind.2017.02.040, 2017.

Tate, E.: Social vulnerability indices: A comparative assessment using uncertainty and sensitivity analysis, Nat. Hazards, 63, 325-347, https://doi.org/10.1007/s11069-012-0152-2, 2012.

Tschakert, P., Ellis, N. R., Anderson, C., Kelly, A., Obeng, J.: One thousand ways to experience loss: A systematic analysis of climaterelated intangible harm from around the world, Global Environ. Chang., 5, 58-72, https://doi.org/10.1016/j.gloenvcha.2018.11.006, 2019.

Turner, B. L., Kasperson, R. E., Matson, P. A., McCarthy, J. J., Corell, R. W., Christensen, L., Eckley, N., Kasperson, J. X., Luers, A., Martello, M. L., Polsky, C., Pulsipher, A., and Schiller, A.: A framework for vulnerability analysis in sustainability science, Proc. Natl. Acad. Sci., 100, 8074-8079, https://doi.org/10.1073/pnas.1231335100, 2003.

Török, I.: Assessment of social vulnerability to natural hazards in Romania, Carpath. J. Earth Env., 12, 549-562, 2017.

Török, I.: Qualitative assessment of social vulnerability to flood hazards in Romania, Sustainability, 10, 1-20, https://doi.org/10.3390/su10103780, 2018.

Wisner, B., Blaikie, P., Cannon, T., and Davis, I. (eds): At risk: Natural hazards, people's vulnerability and disasters (2nd ed.), Oxford: Routledge, 2004.

World Bank: Cluj County RAS, 2020.

Zanetti, V. B., De Sousa W. C., and De Freitas, D. M.: A Climate Change Vulnerability Index and Case Study in a Brazilian Coastal City., Sustain., 8. https://doi.org/10.3390/su8080811, 2016. 
https://doi.org/10.5194/nhess-2021-45

Preprint. Discussion started: 16 March 2021

(c) Author(s) 2021. CC BY 4.0 License.

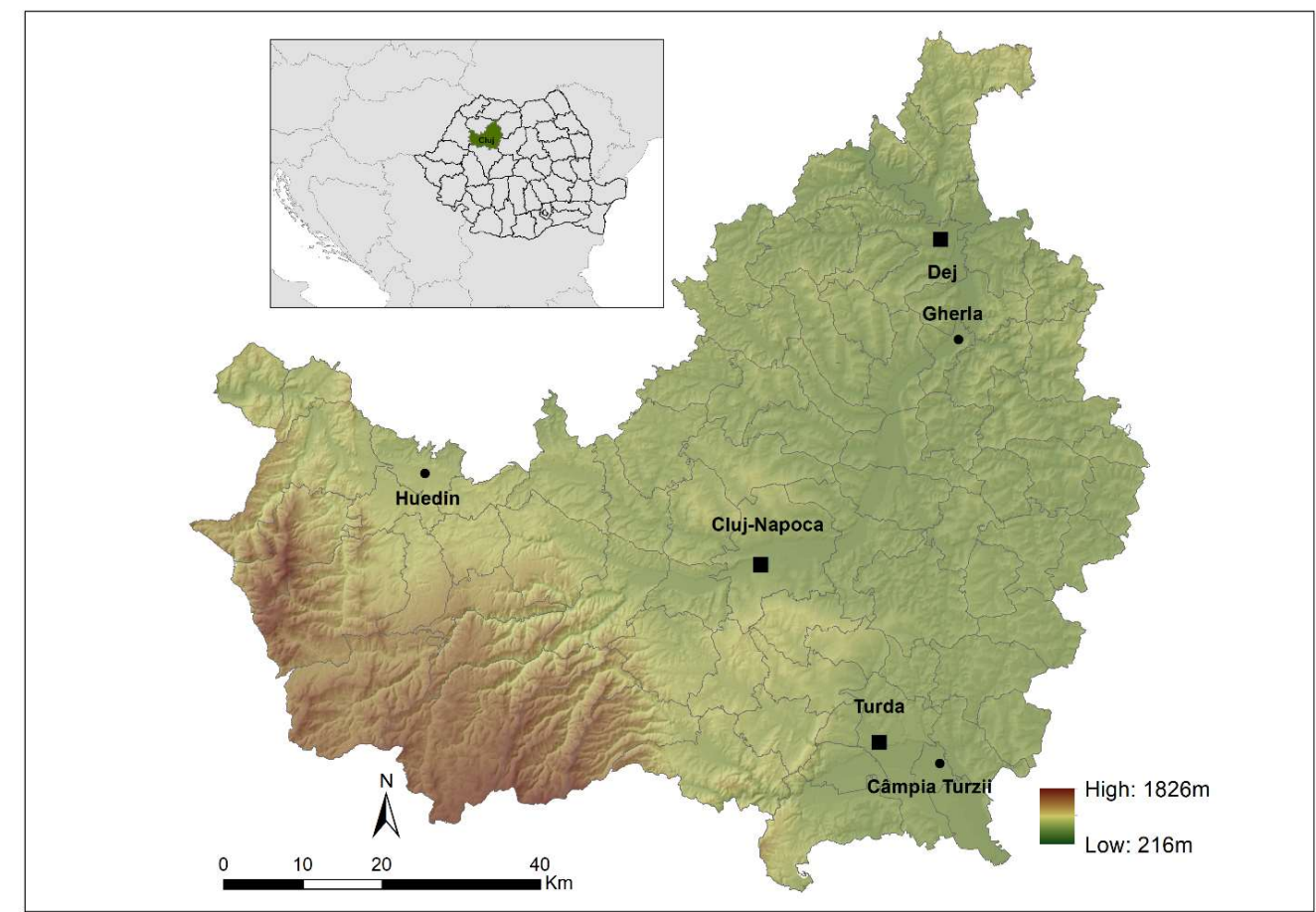

Figure 1: Study area location. 


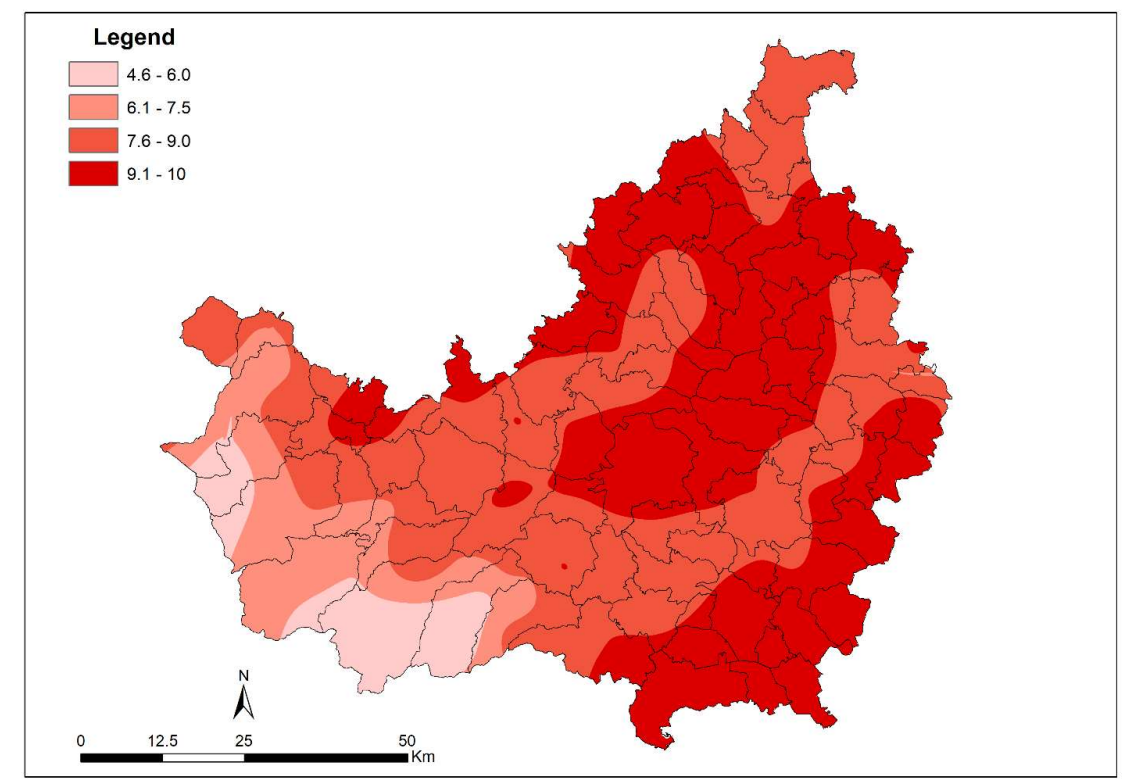

Figure 2: Mean multiannual temperature in Cluj County over the period 1961-2013. Data source: data processed after ROCADA gridded database (Dumitrescu and Birsan, 2015)
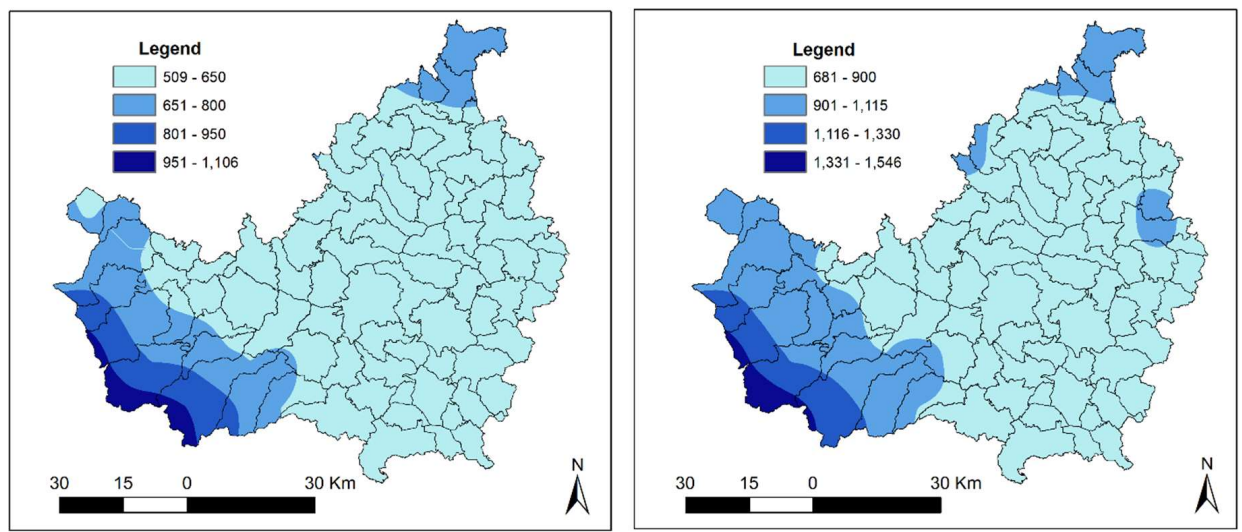

Figure 3: Mean (left) and maximum (right) multiannual amount of precipitation cumulated in wet days (days with precipitation amount equal or greater than $1.0 \mathrm{~mm})$ in Cluj County over the period 1961-2013 (mm/an). Data source: data processed after ROCADA gridded database (Dumitrescu and Birsan, 2015). 
https://doi.org/10.5194/nhess-2021-45

Preprint. Discussion started: 16 March 2021

(c) Author(s) 2021. CC BY 4.0 License.

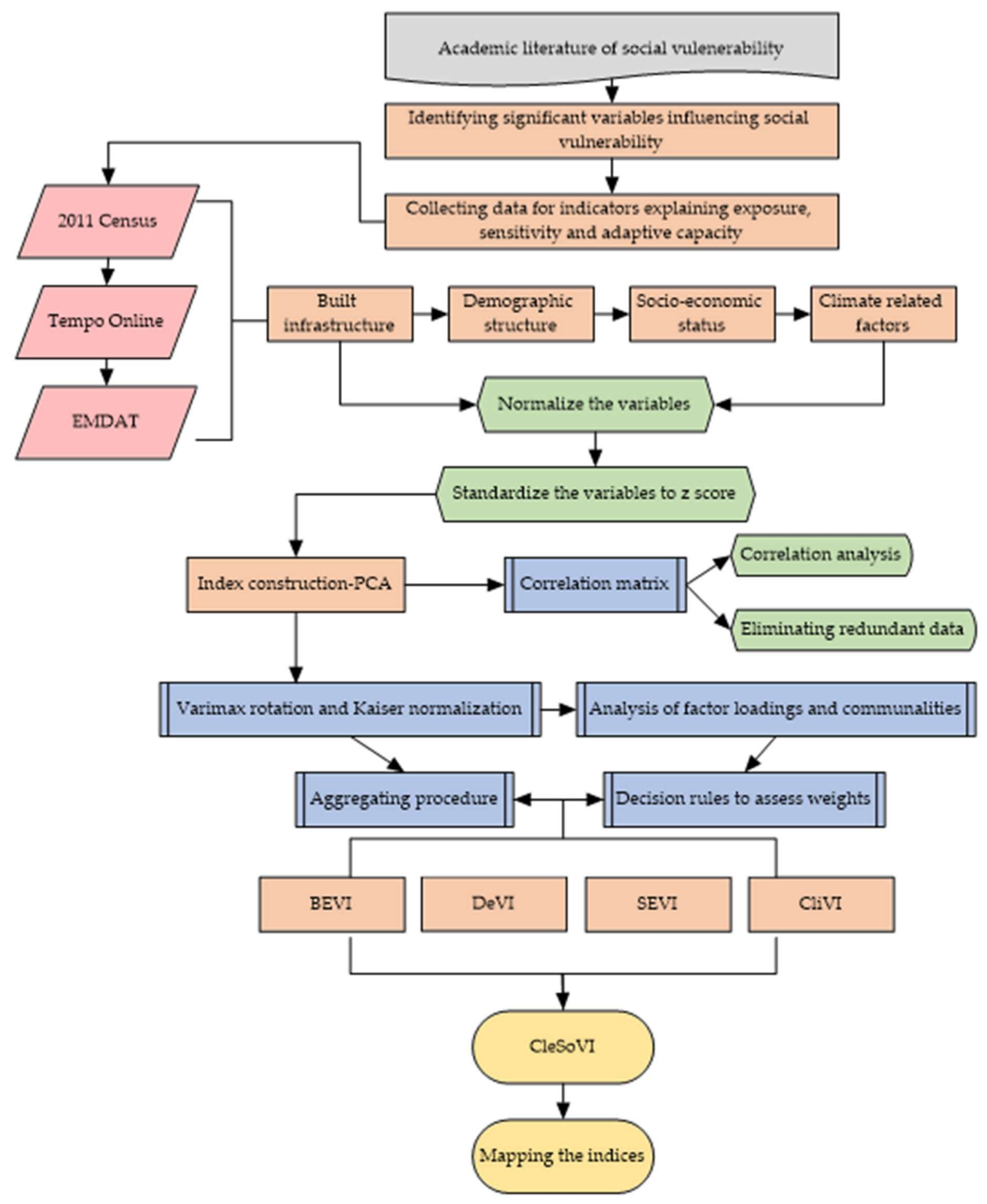

Figure 4: Construction flowchart of the Climate related Social Vulnerability Index (CleSoVI) 
https://doi.org/10.5194/nhess-2021-45

Preprint. Discussion started: 16 March 2021

(c) Author(s) 2021. CC BY 4.0 License.
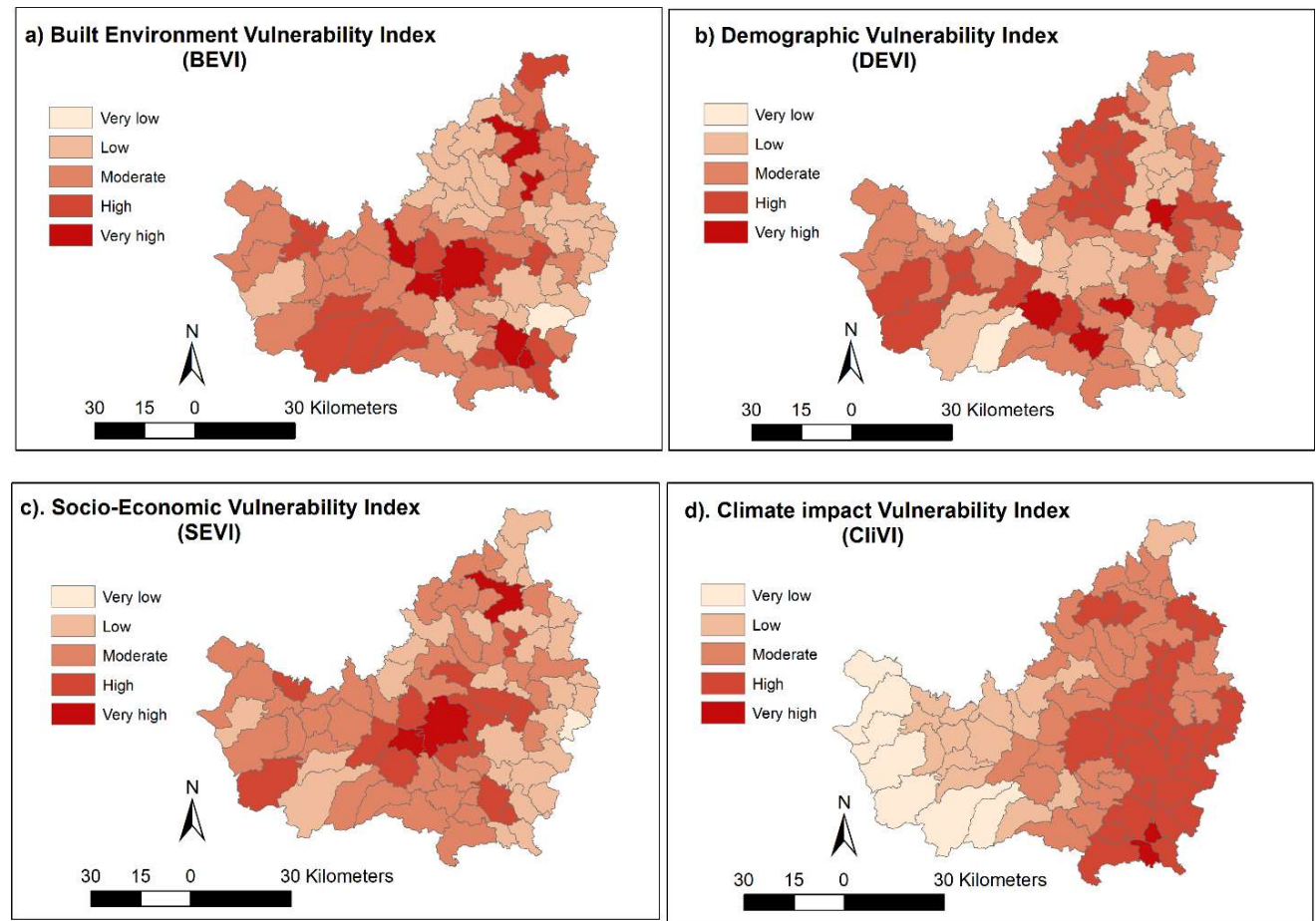

Figure 5: Built-, Demographic-, Socio-Economic and Climate impact vulnerability in Cluj County 
https://doi.org/10.5194/nhess-2021-45

Preprint. Discussion started: 16 March 2021

(c) Author(s) 2021. CC BY 4.0 License.

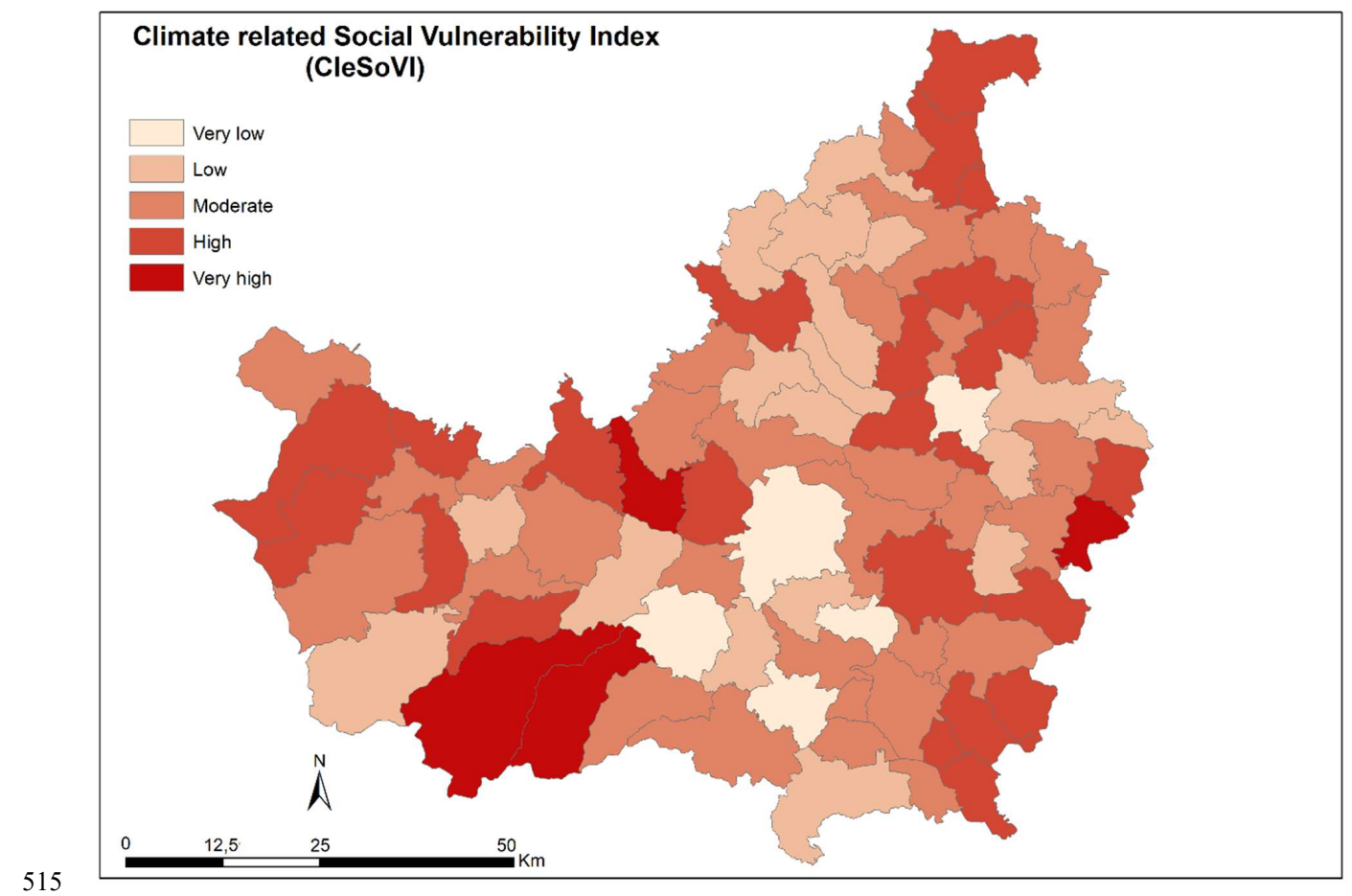

Figure 6: Climate related Social Vulnerability Index scores 
Table 1. Descriptive statistics of variables considered for social vulnerability assessment.

\begin{tabular}{|c|c|c|c|c|c|}
\hline $\begin{array}{l}\text { Vulnerability } \\
\text { components }\end{array}$ & Variables & Mean & $\mathrm{SD}$ & Min & Max \\
\hline \multirow{13}{*}{ Exposure } & Growing degree days $\left({ }^{\circ} \mathrm{C}\right)$ & 1174.42 & 178.11 & 593.60 & 1378.56 \\
\hline & Historical maximum temperature $\left({ }^{\circ} \mathrm{C}\right)$ & 36.86 & 1.81 & 31.30 & 38.86 \\
\hline & Intensity (magnitude) of cold waves $\left({ }^{\circ} \mathrm{C}^{2}\right)$ & -20.95 & 2.05 & -25.09 & -16.91 \\
\hline & $\begin{array}{l}\text { Maximum annual number of hot days (maximum } \\
\text { temperature }>=35^{\circ} \mathrm{C} \text { ) (days) }\end{array}$ & 7.25 & 4.34 & 0.01 & 17.37 \\
\hline & $\begin{array}{l}\text { Mean annual frequency (cumulative duration) of heat } \\
\text { waves (days) }\end{array}$ & 16.12 & 0.31 & 15.49 & 16.69 \\
\hline & $\begin{array}{l}\text { Mean annual number of frost days (maximum } \\
\text { temperature }<0{ }^{\circ} \mathrm{C} \text { ) (days) }\end{array}$ & 117.83 & 8.13 & 107.21 & 144.99 \\
\hline & $\begin{array}{l}\text { Mean annual number of summer days (maximum } \\
\text { temperature }>=25^{\circ} \mathrm{C} \text { ) (days) }\end{array}$ & 51.58 & 15.14 & 11.25 & 72.69 \\
\hline & Mean annual value of daily minimum temperature $\left({ }^{\circ} \mathrm{C}\right)$ & 3.76 & 0.68 & 1.77 & 4.54 \\
\hline & $\begin{array}{l}\text { Mean annual number of tropical days (maximum } \\
\text { temperature }>=30^{\circ} \mathrm{C} \text { ) (days) }\end{array}$ & 9.44 & 4.32 & 0.47 & 17.46 \\
\hline & Mean annual temperature $\left({ }^{\circ} \mathrm{C}\right)$ & 8.73 & 0.86 & 5.83 & 9.76 \\
\hline & Mean duration of a heat wave events (days) & 7.00 & 0.15 & 6.62 & 7.21 \\
\hline & Mean value of daily maximum temperature $\left({ }^{\circ} \mathrm{C}\right)$ & 13.64 & 1.16 & 9.99 & 15.00 \\
\hline & $\begin{array}{l}\text { Percentage of very hot days (maximum temperature }> \\
\text { the } 90^{\text {th }} \text { percentile) }(\%)\end{array}$ & 13.05 & 0.15 & 12.86 & 13.40 \\
\hline \multirow{18}{*}{ Sensitivity } & Average number of people per household & 2.55 & 0.26 & 2.02 & 3.12 \\
\hline & Demographic dependency ratio & 217.50 & 77.14 & 67.31 & 488.81 \\
\hline & Illiteracy rate & 1.85 & 1.70 & 0.24 & 9.93 \\
\hline & Net international migration rate & -0.12 & 0.45 & -2.00 & 1.19 \\
\hline & Number of housing units per square kilometer & 2.17 & 0.94 & 0.77 & 8.37 \\
\hline & People employed in agriculture & 37.30 & 19.11 & 1.06 & 77.50 \\
\hline & Percentage of forest cover & 21.58 & 15.20 & 0.97 & 87.69 \\
\hline & Population density & 97.42 & 237.95 & 6.03 & 1710.87 \\
\hline & Rate of natural increase & -8.63 & 6.50 & -27.80 & 13.52 \\
\hline & Share of diseases of the circulatory system & 7.07 & 19.21 & 0.00 & 90.91 \\
\hline & Share of houses constructed from wood & 16.46 & 16.60 & 1.10 & 68.62 \\
\hline & Share of houses built between 1946-1990 & 27.33 & 8.57 & 9.05 & 46.38 \\
\hline & Share of population under 5 years old & 14.79 & 5.74 & 3.23 & 53.18 \\
\hline & Share of population aged 65 years and above & 30.36 & 10.66 & 8.46 & 66.58 \\
\hline & Share of widows within the female population & 12.97 & 4.41 & 3.80 & 30.77 \\
\hline & Share of women from the total population & 46.84 & 7.76 & 13.91 & 84.19 \\
\hline & Social welfare rates & 52.80 & 13.99 & 34.86 & 99.59 \\
\hline & Access to major public road network & 2.22 & 1.22 & 1.00 & 5.00 \\
\hline
\end{tabular}


https://doi.org/10.5194/nhess-2021-45

Preprint. Discussion started: 16 March 2021

(c) Author(s) 2021. CC BY 4.0 License.

Employment rate

Housing space per person

Local Human Development Index

Medical-sanitary staff per 1000 persons

Number of houses with reinforced structure

People employed in services

Adaptive

capacity

Per capita income

Share of houses built after 1990

Share of households with a kitchen area

Share of households with a fixed bath

Share of households with access to piped water

Share of households with access to the sewage network

Share of households with central heating system

Share of population with university education

\begin{tabular}{rrrr}
0.30 & 0.28 & 0.05 & 1.79 \\
19.29 & 7.90 & 5.25 & 61.14 \\
55.24 & 17.53 & 0.00 & 106.27 \\
0.67 & 1.16 & 0.00 & 8.56 \\
0.54 & 0.79 & 0.00 & 5.00 \\
39.20 & 14.80 & 15.06 & 82.79 \\
971.63 & 451.70 & 249.13 & 3908.83 \\
14.18 & 9.90 & 3.19 & 51.13 \\
69.50 & 18.02 & 28.30 & 97.94 \\
42.30 & 22.84 & 6.67 & 97.62 \\
48.35 & 23.48 & 12.61 & 98.65 \\
45.95 & 23.40 & 10.90 & 98.52 \\
17.90 & 20.54 & 1.49 & 92.02 \\
5.89 & 5.92 & 1.00 & 37.51 \\
\hline
\end{tabular}

Notes: $\mathrm{SD}=$ Standard Deviation. Max $=$ Maximum value. Min $=$ Minimum value. $\mathrm{N}=81$ 
Table 2. Main components and variables, explained variance and loadings for the CleSoVI analysis

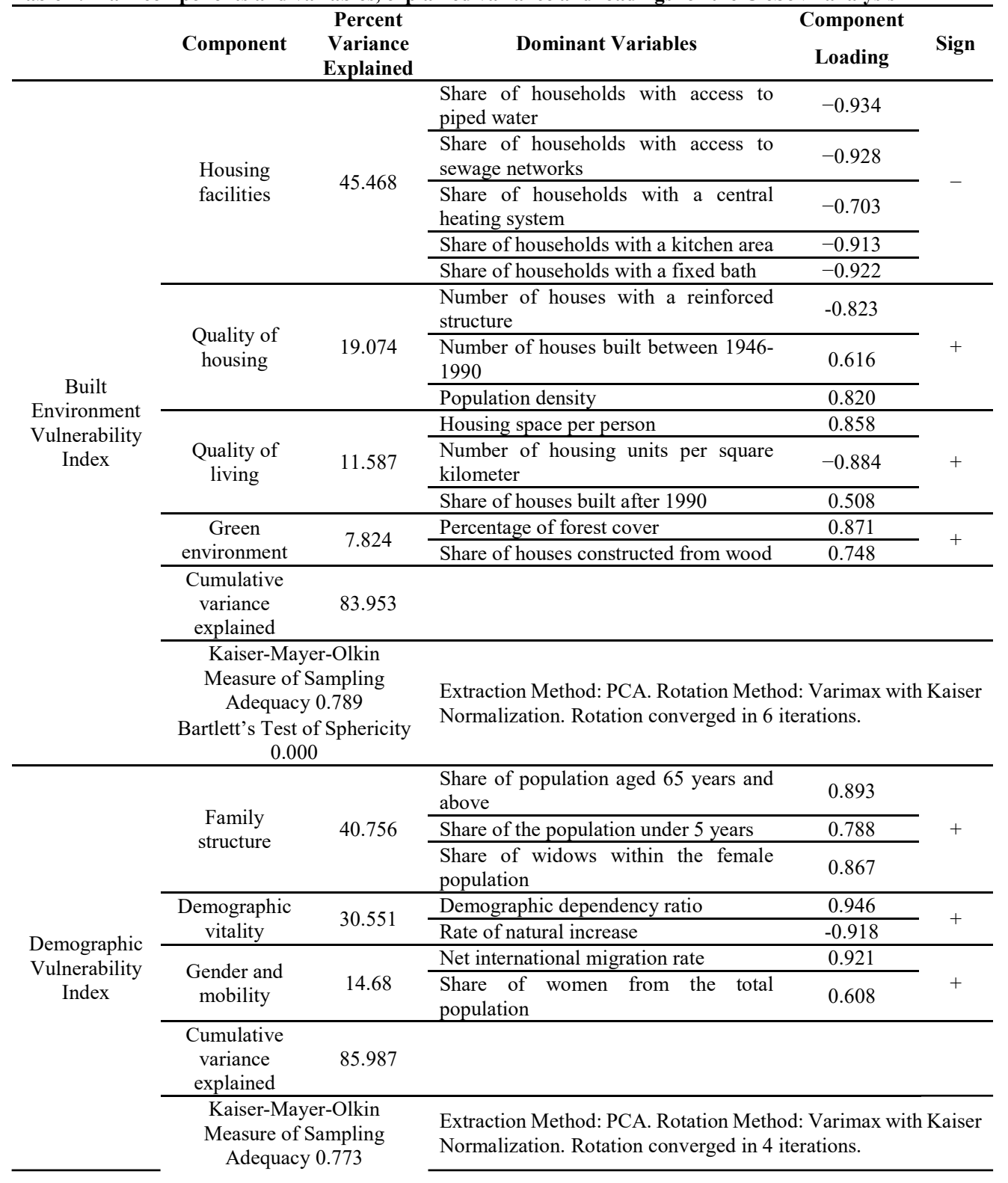




\begin{tabular}{|c|c|c|c|c|c|}
\hline & \multicolumn{2}{|c|}{$\begin{array}{c}\text { Bartlett's Test of Sphericity } \\
0.000 \\
\end{array}$} & & & \\
\hline \multirow{14}{*}{$\begin{array}{c}\text { Socio- } \\
\text { Economic } \\
\text { Vulnerability } \\
\text { Index }\end{array}$} & \multirow{6}{*}{$\begin{array}{l}\text { Education and } \\
\text { occupation }\end{array}$} & \multirow{6}{*}{45.554} & $\begin{array}{l}\text { Share of population with a university } \\
\text { education }\end{array}$ & -0.830 & \multirow{6}{*}{-} \\
\hline & & & Employment rate & -0.802 & \\
\hline & & & Illiteracy rate & 0.571 & \\
\hline & & & Local Human Development Index & -0.794 & \\
\hline & & & People employed in agriculture & 0.842 & \\
\hline & & & People employed in services & -0.853 & \\
\hline & \multirow{3}{*}{$\begin{array}{l}\text { Health and } \\
\text { accessibility }\end{array}$} & \multirow{3}{*}{19.871} & Access to major public roads & -0.647 & \multirow{3}{*}{-} \\
\hline & & & Medical sanitary staff per 1000 persons & -0.925 & \\
\hline & & & $\begin{array}{l}\text { Share of diseases of the circulatory } \\
\text { system }\end{array}$ & 0.935 & \\
\hline & \multirow{3}{*}{$\begin{array}{l}\text { General well- } \\
\text { being }\end{array}$} & \multirow{3}{*}{10.871} & $\begin{array}{l}\begin{array}{l}\text { Average number of people } \\
\text { household }\end{array} \\
\end{array}$ & 0.858 & \multirow{4}{*}{-} \\
\hline & & & Social welfare rates & -0.925 & \\
\hline & & & Per capita income & -0.656 & \\
\hline & $\begin{array}{l}\text { Cumulative } \\
\text { variance } \\
\text { explained } \\
\end{array}$ & 76.296 & & & \\
\hline & \multicolumn{2}{|c|}{$\begin{array}{c}\text { Kaiser-Mayer-Olkin } \\
\text { Measure of Sampling } \\
\text { Adequacy } 0.750 \\
\text { Bartlett's Test of Sphericity } \\
0.000 \\
\end{array}$} & \multicolumn{3}{|c|}{$\begin{array}{l}\text { Extraction Method: PCA. Rotation Method: Varimax with Kaiser } \\
\text { Normalization. Rotation converged in } 6 \text { iterations. }\end{array}$} \\
\hline \multirow{13}{*}{$\begin{array}{c}\text { Climate } \\
\text { vulnerability } \\
\text { index }\end{array}$} & \multirow{11}{*}{$\begin{array}{c}\text { Extreme } \\
\text { temperature } \\
\text { indices }\end{array}$} & \multirow{11}{*}{78.964} & Mean annual temperature & 0.959 & \multirow{11}{*}{+} \\
\hline & & & Historical maximum temperature $\left({ }^{\circ} \mathrm{C}\right)$ & 0.947 & \\
\hline & & & $\begin{array}{l}\text { Mean value of daily maximum } \\
\text { temperature }\left({ }^{\circ} \mathrm{C}\right)\end{array}$ & 0.949 & \\
\hline & & & $\begin{array}{l}\text { Mean annual value of daily minimum } \\
\text { temperature }\left({ }^{\circ} \mathrm{C}\right)\end{array}$ & 0.969 & \\
\hline & & & $\begin{array}{l}\text { Mean duration of a heat wave events } \\
\text { (days) }\end{array}$ & 0.791 & \\
\hline & & & $\begin{array}{l}\text { Mean annual number of summer days } \\
\text { (maximum temperature }>=25^{\circ} \mathrm{C} \text { ) }\end{array}$ & 0.947 & \\
\hline & & & $\begin{array}{l}\text { Mean annual number of tropical days } \\
\text { (maximum temperature }>=30^{\circ} \mathrm{C} \text { ) }\end{array}$ & 0.897 & \\
\hline & & & $\begin{array}{l}\text { Maximum annual number of hot days } \\
\text { (maximum temperature }>=35^{\circ} \mathrm{C} \text { ) }\end{array}$ & 0.836 & \\
\hline & & & $\begin{array}{l}\text { Percentage of very hot days (maximum } \\
\text { temperature }>\text { the } 90^{\text {th }} \text { percentile) }(\%)\end{array}$ & 0.728 & \\
\hline & & & $\begin{array}{l}\text { Mean annual number of frost days } \\
\text { (maximum temperature }<0{ }^{\circ} \mathrm{C} \text { ) }\end{array}$ & 0.967 & \\
\hline & & & Growing degree days $\left({ }^{\circ} \mathrm{C}\right)$ & 0.952 & \\
\hline & \multirow{2}{*}{$\begin{array}{c}\text { Heat wave } \\
\text { duration } \\
\text { indices }\end{array}$} & \multirow{2}{*}{12.77} & $\begin{array}{l}\text { Mean duration of a heat wave events } \\
\text { (days) }\end{array}$ & 0.925 & \multirow{2}{*}{+} \\
\hline & & & $\begin{array}{l}\text { Mean annual frequency (cumulative } \\
\text { duration) of heat waves (days) }\end{array}$ & 0.911 & \\
\hline
\end{tabular}


https://doi.org/10.5194/nhess-2021-45

Preprint. Discussion started: 16 March 2021

(c) Author(s) 2021. CC BY 4.0 License.

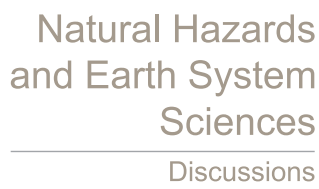

\section{Cumulative \\ variance \\ 89.697}

explained

Kaiser-Mayer-Olkin

Measure of Sampling

Adequacy 0.890

Extraction Method: PCA. Rotation Method: Varimax with

Bartlett's Test of Sphericity

Kaiser Normalization. Rotation converged in 3 iterations. 0.000 